\title{
(Pro)posições do Pacto Nacional pela Alfabetização na Idade Certa para a Educação Especial: uma proposta inclusiva?
}

\author{
(Pro)positions of the Pacto Nacional pela Alfabetização na \\ Idade Certa for the Special Education: An Inclusive Proposal?
}

Marli dos Santos de Oliveira* Giovani Ferreira Bezerra**

BRASIL, Ministério da Educação. Secretaria de Educação Básica. Caderno de Educação Especial - A alfabetizaçáo de crianças com deficiência: uma proposta inclusiva.

Diretoria de Apoio à Gestão Educacional. Brasília, 2012.

O caderno de educação especial $A$ alfabetização de crianças com deficiência: uma proposta inclusiva constitui-se como um dos vários materiais criados pelo $\mathrm{Mi}$ nistério da Educação para auxiliar os docentes em relação às novas exigências do Pacto Nacional pela Alfabetização na Idade Certa. Tal pacto se apresenta como um compromisso formal assumido pelo governo federal, estados e municípios, a fim de assegurar que todas as crianças estejam alfabetizadas até os oito anos de idade, ao final do $3^{\circ}$ ano do ensino fundamental.

Organizado em seis capítulos, o caderno busca discutir sobre a Educação Especial na perspectiva da Educação Inclusiva, sob a ótica de diversos autores/as: Tícia Cassiany Ferro Cavalcante, Ana Gabriela de Souza Leal, Wilma Pastor de Andrade Sousa, Carlos Antonio Fontenele Mourão e Rafaella Asfora. As orientações propostas neste caderno buscam ampliar e potencializar as possibilidades de ensino e orientar a utilização de jogos e brincadeiras em contextos inclusivos de alfabetização. Entretanto, o material se restringe somente à alfabetização de crianças com deficiência de ordem motora, cognitiva e sensorial (visual ou auditiva), não abordando casos de altas habilidades, nem os transtornos globais do desenvolvimento.

O capítulo I, intitulado A pessoa com deficiência motora frente ao processo de alfabetização, apresenta uma breve caracterizaçâo do que é a deficiência motora, focalizando as discussóes nos alunos com paralisia cerebral. Argumenta-se que esta se coloca como uma das principais causas de deficiência motora presente nas escolas.

\footnotetext{
* Acadêmica do curso de Pedagogia da Universidade Federal de Mato Grosso do Sul (UFMS/CPNV), Naviraí, Mato Grosso do Sul, Brasil.

** Professor na Universidade Federal de Mato Grosso do Sul (UFMS/CPNV), Naviraí, Mato Grosso do Sul, Brasil.
} 
Em seguida, descreve que a falta de recursos de acessibilidade e de comunicação das pessoas com deficiência nem sempre está relacionada estritamente à questão financeira, uma vez que o professor pode utilizar sua criatividade para construí-los e/ou realizá-los. Enfatiza, ainda, que a Comunicação Alternativa e Suplementar (CAS) possibilita a erradicação das barreiras de comunicação presentes na escola, ocorrendo de forma eficaz à medida que o professor cria laços com o aluno, conhecendo-o em suas especificidades.

O capítulo II, Pensando a alfabetização da pessoa com deficiência intelectual, discute alguns aspectos históricos da deficiência intelectual, demonstrando que a escola náo está adequada para atender as diferenças de crianças sem qualquer deficiência e, sobretudo, para atender (sem segregar) as necessidades das crianças com deficiência. Em seguida, destaca que a deficiência intelectual náo pode ser encarada como uma condição estática, e nem apenas sob a ótica dos impedimentos que a pessoa nessa condição pode ter. Descreve que o trabalho docente, juntamente com o apoio da família, deve estar direcionado para a perspectiva de que a criança aprende em sua interação com o mundo, mediante as oportunidades a ela destinadas, no decorrer de sua trajetória de vida, sendo capaz de se comunicar, se alfabetizar, enfim, de aprender.

Seguindo com as discussōes, o capítulo III, Estratégias de ensino na alfabetização da pessoa cega e com baixa visão, inicia discutindo que, durante a história das pessoas com deficiência, no Brasil, a cegueira foi sempre caracterizada pelo impedimento e incapacidade do sujeito. Em seguida, apresenta uma caracterização da deficiência visual, demonstrando que a visão não é a única forma para a locomoção e interação com o mundo, e que as pessoas com deficiência são iguais às demais em relação a suas capacidades produtivas e relacionais, podendo desenvolver açôes em várias esferas da sociedade, desde que lhe sejam ofertadas as condiçóes necessárias. Desse ângulo, não basta somente a escola apresentar a escrita braille à criança com deficiência visual, pois esta, sozinha, não garantirá a sua alfabetização, sendo necessário que o professor utilize vários instrumentos que desenvolvam e explorem os demais sentidos.

No capítulo IV, A alfabetização da pessoa surda: desafios e possibilidades, discute-se que a alfabetizaçáo da pessoa surda em Língua Portuguesa é encarada como um dos grandes desafios de escolarizaçâo desses sujeitos. Ressalta-se que a perda total ou parcial da audição não significa incapacidade cognitiva, sendo que as condiçóes e situaçóes ofertadas à pessoa com surdez influenciam em seu desenvolvimento, bem como em suas relaçôes escolares e sociais. Nesse sentido, para que ocorra a alfabetização da pessoa com deficiência auditiva, é necessário que ela visualize seu professor, intérprete e/ou professor intérprete, estabelecendo uma relação de confiança, sendo-lhe um direito a comunicaçáo e o esclarecimento de todas suas dúvidas. Logo, é necessário que os professores dominem a Língua Portuguesa, bem como a Língua Brasileira de Sinais, para que, primeiramente, a partir desta última, se consiga alfabetizar a pessoa com deficiência auditiva, proporcionando-lhe a comunicação e o aprendizado.

O capítulo V, O Atendimento Educacional Especializado nas Salas de Recursos Multifuncionais, inicia situando o leitor historicamente acerca das muitas conquistas em relação aos direitos das pessoas com deficiência, sendo que o direito à educaçáo e 
a aprendizagem devem ocorrer em um sistema educacional inclusivo, que disponha de recursos e serviços especializados para que a pessoa com deficiência se desenvolva com igualdade de acesso e permanência às escolas comuns.

Nessa direção, o Atendimento Educacional Especializado (AEE), que acontece em salas de recursos multifuncionais, no contraturno, coloca-se também como um importante direito conquistado a partir da Política Nacional de Educação Especial na Perspectiva de uma Educação Inclusiva, oficializada em 2008. Na sequência, o capítulo apresenta algumas definiçôes sobre o público-alvo do AEE, sobre os materiais disponibilizados nas salas de recursos multifuncionais de tipo I e II, salientando que cabe ao profissional do AEE trabalhar de modo articulado com o professor da escola regular. Finaliza-se o capítulo com diversas sugestóes acerca do trabalho que o profissional especialista deve realizar com os alunos com cegueira, baixa visão, surdez, deficiência física e deficiência intelectual.

Encerrando as discussões do Caderno de Educação Especial, o capítulo VI, Compartilhando, é subdividido em três tópicos e não trata especificamente sobre uma deficiência em particular. Nesta ordem, aborda-se uma sequência didática acerca de um projeto desenvolvido por uma professora com alunos surdos do $1^{\circ}$ e $2^{\circ}$ anos do ensino fundamental; apresentam-se relatos de experiências de uma professora sobre a inclusão de um aluno com paralisia cerebral, bem como relatos de outra professora sobre a inclusão de uma aluna com Síndrome de Down em uma turma de $1^{\circ}$ ano do ensino fundamental; e, por fim, aborda-se o uso de jogos para a alfabetização numa perspectiva inclusiva. Ao término do livro, aparecem, ainda, algumas sugestóes de leituras para que o leitor/professor possa refletir mais sobre a Educação Especial na perspectiva da Educaçáo Inclusiva.

Percebe-se, todavia, com a leitura do Caderno de Educação Especial, que esse material disponibilizado aos professores alfabetizadores apresenta algumas lacunas. Primeiramente, no que diz respeito à brevidade das abordagens que compóem o material, visto que as orientaçóes feitas aos professores ocorrem minimamente sobre algumas especificidades dos alunos com deficiência, não havendo nenhum outro material no contexto do Pacto Nacional pela Alfabetização na Idade Certa que contemple a Educação Especial na perspectiva da Educação Inclusiva. Além disso, não se discorre sobre as possibilidades de alfabetização dos alunos com altas habilidades e com transtornos globais do desenvolvimento.

Nesse sentido, ao se considerar o objetivo de se alfabetizar todas as crianças, é necessário subsidiar os docentes tanto no que se refere aos materiais diversificados, quanto, sobretudo, em sua formação. De forma análoga, outra questão que merece atenção diz respeito à responsabilidade demasiadamente atribuída ao professor. $\mathrm{O}$ Caderno de Educação Especial, em sua totalidade, dirige-se aos professores como sendo os únicos responsáveis por criar materiais e recursos diversos para contribuir no processo de alfabetização das crianças com necessidades educacionais especiais, desconsiderando-se que este trabalho deve ser realizado de modo conjunto, pela instituição escolar e por demais profissionais que apoiem o trabalho pedagógico especializado. 
Como apreciação final, pode-se dizer que pensar a alfabetização de todas as crianças da rede regular de ensino exige, de início, uma compreensão de totalidade por parte dos elaboradores desses materiais de formação docente, bem como das políticas educacionais, sobretudo no que tange à Educação Especial na perspectiva de Educação Inclusiva. Afinal, este "Pacto de Alfabetização" deve ser firmado com todas as crianças brasileiras, respeitando-as em suas diferenças e necessidades.

\section{Correspondência}

Marli dos Santos de Oliveira - Universidade Federal de Mato Grosso do Sul, Campus Universitário de Naviraí. MS 141, KM 4, Zona Rural, CEP: 79950-000 - Naviraí, Mato Grosso do Sul - Brasil.

E-mail: marli.oliveiras@hotmail.com - gfbezerra@gmail.com

Recebido em 13 de julho de 2013

Aprovado em 17 de julho de 2014 